\title{
Immobilization of Gluconobacter oxydans by Entrapment in Porous Chitosan Sponge
}

Cunxun Wang, Kefeng Ni, Xu Zhou, Dongzhi Wei and Yuhong Ren*

State Key Laboratory of Bioreactor Engineering, New World Institute of Biotechnology, East China University of Science and Technology, Shanghai 200237, China

\begin{abstract}
The porous chitosan sponge was prepared using $\mathrm{NaHCO}_{3}$ as the porogen and used to immobilize Gluconobacter oxydans. Under the optimum conditions, the activity recovery of the immobilized cells reached $92 \%$. The morphology characterization of the immobilized cells revealed that the cells were attached to the surface of the pores $(100-400 \mu \mathrm{m})$ which were well distributed in the chitosan sponge. The valuation of cell activity showed that the immobilized cells displayed enhanced $\mathrm{pH}$ and thermal stability compared to free cells. Furthermore, the immobilized cells retained $74 \%$ of its origin activity after 12 repeated reaction cycles separated by filtration.
\end{abstract}

Keywords: Chitosan sponge; Gluconobacter oxydans; Immobilization; Porogen

\section{Introduction}

Gluconobacter oxydans have been widely used to incompletely oxidize sugar, alcohol and aldehyde to produce aldehyde, ketone and acid by its dehydrogenases connected to the respiratory chain [1]. However, G. oxydans is a very small size bacterial leading to difficulties in the reuse or recycling of the cells for large-scale application.

Wholecellimmobilization, which provides cells with easy separation, enhanced stability and reusability, has been proved to be an efficient solution [2]. As the immobilization matrices, natural polymers such as agar, alginate, carrageenan and chitosan have received considerable attention due to their high biocompatibility [3], and a variant of the whole cell immobilization technique have been developed. Chitosan, the second most abundant natural polymer found in the exoskeleton of marine crustaceans, has gained great interest in immobilization technology [4]. It is also supposed to be very interest substance for diverse applications in biomaterial such as in preparing films [5], beads [6], scaffolds [7], hydrogels [8], nanofibers [9] and nanoparticles [10] in the pharmaceutical field due to its biocompatibility, biodegradability and bioactivity.

In this study, we proposed a novel method to immobilize $G$. oxydans in the chitosan spongy material which was synthesized using $\mathrm{NaHCO}_{3}$ as the porogen to react with acetic acid producing $\mathrm{CO}_{2}$ and forming pores in chitosan sponge. Compared with other porogen such as polyethylene glycol [11] and silica [12,13], $\mathrm{NaHCO}_{3}$ can be removed in mild condition leading to a higher cell activity recovery. After immobilized, the cells were easily separated from the solution by filtering, and their thermal and $\mathrm{pH}$ stability and reusability were increased.

\section{Materials and Methods}

\section{Microorganism and cultivation conditions}

The strain G.oxydans DSM 2003 was used in this study. The cells were cultured in $500-\mathrm{mL}$ flasks containing $50 \mathrm{~mL}$ sterile fermentation medium, which contained $80 \mathrm{~g}$ sorbitol/L, $20 \mathrm{~g}$ yeast extract/L, $1 \mathrm{~g}$ $\mathrm{KH}_{2} \mathrm{PO}_{4} / \mathrm{L}, 0.5 \mathrm{~g} \mathrm{MgSO}_{4} / \mathrm{L}, 0.1 \mathrm{~g}$ Glutamine/L. The cells were incubated at $30^{\circ} \mathrm{C}$ with shaking at $200 \mathrm{rpm}$ for $24 \mathrm{~h}$ and collected by centrifugation.

\section{Immobilization of G. oxydans}

Chitosan (1.5 g) was dissolved in $2 \%(\mathrm{v} / \mathrm{v})$ acetic acid $(100 \mathrm{~mL})$, and then the $\mathrm{pH}$ of the solution was adjusted to 5.0 using $2 \mathrm{M} \mathrm{NaOH}$. $5 \mathrm{~mL}$ G. oxydans suspension ( $10 \mathrm{~g}$ cells/L, dry weight) was added to the above solution followed by the addition of $10 \mathrm{~mL}$ the mixture of $\mathrm{NaHCO}_{3}(10 \% \mathrm{w} / \mathrm{v})$ and glutaraldehyde $(5 \% \mathrm{w} / \mathrm{v})$. The reaction mixture was further stirred at room temperature until formatting the porous chitosan sponge with cells embeded. The immobilized cells were filtered and washed several times with phosphate buffer ( $\mathrm{pH}$ 6.0). The density of free cells in the solution was determined by measuring the optical density of the cell suspension at $600 \mathrm{~nm}$ (OD600) with a spectrophotometer (U-2001; Hitachi, Tokyo). The difference in cell density was used to calculate immobilization efficiency. The morphology of the immobilized cells was observed on a Scanning electron microscopy (SEM) (JEOL Japan). Samples were lyophilized and sputter-coated with gold prior to scanning.

\section{Activity assay}

The activity of cells was determined by measuring the production of dihydroxy acetone (DHA) from glycerol. The reaction was carried out at $30^{\circ} \mathrm{C}$ in phosphate buffer $(\mathrm{pH} 6.0,10 \mathrm{mM})$ containing $10 \mathrm{~g}$ glycerol/L. After reacting for 1 hour, the free cells were separated by centrifugation and the immobilized cells were separated by filtration. The reaction products were analyzed by HPLC using a COREGEL $87 \mathrm{H} 3$ column (Transgenomic, USA) with isocratic elution of $4 \mathrm{mM} \mathrm{H}_{2} \mathrm{SO}_{4}$.

\section{Stability and reusability}

Effect of temperature and $\mathrm{pH}$ on the activity of immobilized cells were determined from $20-50^{\circ} \mathrm{C}$ and $\mathrm{pH}$ 5-8.5 and compared with free cells. The reusability of the immobilized cells was assessed under the same conditions as described in activity assay section.

*Corresponding author: Yuhong Ren, State Key Laboratory of Bioreacto Engineering, New World Institute of Biotechnology, East China University of Science and Technology, Shanghai 200237, China, Tel: +86-2164252163; Fax: +86-2164250068; Email: yhren@ecust.edu.cn

Received August 08, 2013; Accepted August 22, 2013; Published August 30 , 2013

Citation: Wang C, Ni K, Zhou X, Wei D, Ren Y (2013) Immobilization of Gluconobacter oxydans by Entrapment in Porous Chitosan Sponge. J Bioprocess Biotech 3: 132 doi: 10.4172/2155-9821.1000132

Copyright: ( 2013 Wang C, et al. This is an open-access article distributed unde the terms of the Creative Commons Attribution License, which permits unrestricted use, distribution, and reproduction in any medium, provided the original author and source are credited. 
Citation: Wang C, Ni K, Zhou X, Wei D, Ren Y (2013) Immobilization of Gluconobacter oxydans by Entrapment in Porous Chitosan Sponge. J Bioprocess Biotech 3: 132 doi: 10.4172/2155-9821.1000132

Page 2 of 3

\section{Results and Discussion}

\section{Morphology of the biocarrier}

Figure 1 showed the SEM images of porous chitosan sponge with and without immobilization of G. oxydans. The biocarrier was highly porous and the pores (ranging from 100 to $400 \mu \mathrm{m}$ ) were well distributed with an interconnected pore wall structure. The porous structure of the chitosan sponge was beneficial for cell adhesion and substrates diffusion. As shown in Figure 1d, the chitosan sponge surface without cells entrapment is relatively smoother than the one with cells in Figure 1c which revealed the cells attached to the chitosan sponge and covered a majority of the inner surface of the pores. The internal cells distribution of chitosan sponge was confirmed by Laser Scanning Confocal Microscopy (LSCM) (Supplementary Figure S1) and the results displayed that the cells were well distributed inside the chitosan sponge.

\section{Immobilization of $G$. oxydans}

The effect of glutaraldehyde concentrations showed the cells' activity decreased with the increase of glutaraldehyde (Supplementary Figure S2). However, the chitosan couldn't form a cross-linked sponge when the concentration of glutaraldehyde was less than $0.5 \%(\mathrm{w} / \mathrm{v})$, leading to cells leakage. Hence, the optimum glutaraldehyde concentration was $0.5 \%$ and the cell activity retained more than $90 \%$ at this concentration.

As the porogen, $\mathrm{NaHCO}_{3}$ reacted with acetic acid producing $\mathrm{CO}_{2}$, which formed pores in chitosan sponge. The porosity of chitosan sponge increased with the increase of the concentration of $\mathrm{NaHCO}_{3}$ (Supplementary Table S1). Figure 2 a showed that the activity recovery of immobilized cells increased from $21 \%$ to $92 \%$ when the concentration of $\mathrm{NaHCO}_{3}$ increased from 0 to $10 \%$, but decreased to $62 \%$ as the concentration of $\mathrm{NaHCO}_{3}$ continued to rise to $15 \%$. The improvement of the activity recovery of immobilized cells was attributed to the increase of the porosity of chitosan sponge which was favorable for the diffusion of substrates. However, when the concentration of $\mathrm{NaHCO}_{3}$ was up to $15 \%$ the activity recovery of immobilized cells was decreased quickly due to the alkaline internal condition of chitosan sponge which exceeded the optimum catalytic $\mathrm{pH}$ conditions.

The effect of the concentration of chitosan on the activity recovery of immobilized cells was investigated and the result was showed in Figure 2b. Increasing the concentration of chitosan in the range $0-1.5 \%$ resulted in an increase in the activity recovery from $41 \%$ to $87.5 \%$. However, the activity recovery began to decrease above chitosan

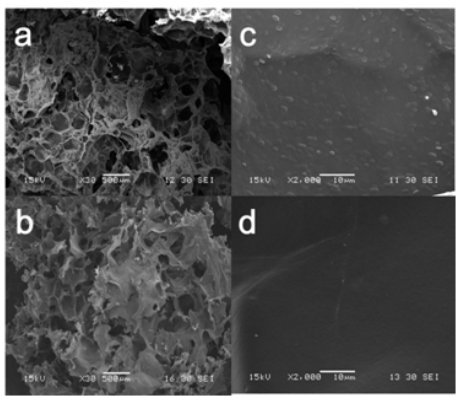

Figure 1: SEM images of porous chitosan sponge. (a) magnification 30x, (b) magnification 30x, (c) magnification 2,000x, (d) magnification 2,000x.
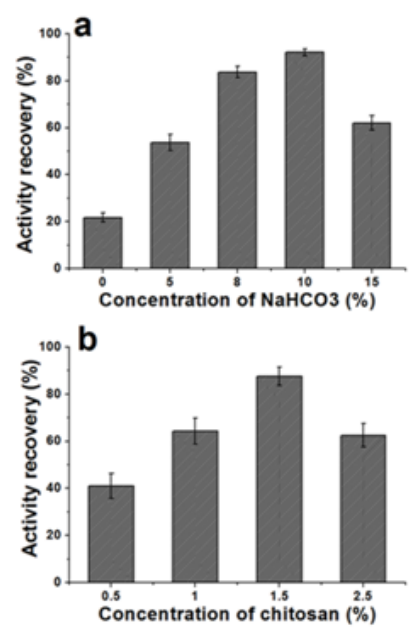

Figure 2: The effect of the concentration of $\mathrm{NaHCO}_{3}$ (a) and chitosan (b) on the activity recovery of immobilized cells. The activity of free cells was defined as $100 \%$.

a: $1.5 \%(w / v)$ glutaraldehyde, $10 \%(w / v) \mathrm{NaHCO}_{3}, 5 \mathrm{mg}$ (dry weight) cells; b: $1.5 \%$ $(\mathrm{w} / \mathrm{v})$ glutaraldehyde, $1.5 \%(\mathrm{w} / \mathrm{v})$ chitosan, $5 \mathrm{mg}$ (dry weight) cells.

concentration of $1.5 \%$, which supposed to be due to the decrease of porosity of the chitosan sponge (Supplementary Table S2).

\section{Effect of $\mathrm{pH}$ and temperature}

Figures $3 \mathrm{a}$ and $3 \mathrm{~b}$ showed that the optimal temperature and $\mathrm{pH}$ for both free and immobilized cells to achieve the highest activity were $30^{\circ} \mathrm{C}$ and $\mathrm{pH}$ 6.0. Compared to the free cells, the immobilized cells retained higher thermal and $\mathrm{pH}$ stability after incubated at various temperatures (Figure 3c) and $\mathrm{pH}$ (Figure 3d). Because the enzyme responsible for DHA synthesis was a membrane bound dehydrogenase, the enhanced stability of immobilized cells may be attributed to the decrease damaged of cell's membrane after the cells were covalently linked to the chitosan sponge by glutaraldehyde.

\section{Reusability}

The reusability of immobilized cells is a very important property in their application. Compared to the free cells separated by centrifugation, the chitosan sponge entrapped cells can be easily separated by filtration and applied for another cycle. As shown in Figure 4, the immobilized cells retained $74 \%$ of its initial activity after 12 cycles, whereas the free cells only retained $50 \%$ of its initial activity. The decrease of activity was caused by the cell inactivation, but not the cell leakage (no cell loss was observed in this process). Furthermore, the cells were hardly leaked from the chitosan sponge even after shaking at $200 \mathrm{rpm}$ for 3 days (data not shown). It was suggested that the cells were covalently linked with chitosan sponge by glutaraldehyde which prevented cells detaching from the carrier.

\section{Conclusion}

Gluconobacter oxydans was immobilized on the porous chitosan sponge with a $92 \%$ activity recovery after optimization. The immobilized cells displayed higher thermal and $\mathrm{pH}$ stability than the free cells. More importantly, the immobilized cells can be easily separated and reused, and retained $74 \%$ of the initial activity even after 12 cycles. These results make the porous chitosan sponge a promising material in cells immobilization applications. 
Citation: Wang C, Ni K, Zhou X, Wei D, Ren Y (2013) Immobilization of Gluconobacter oxydans by Entrapment in Porous Chitosan Sponge. J
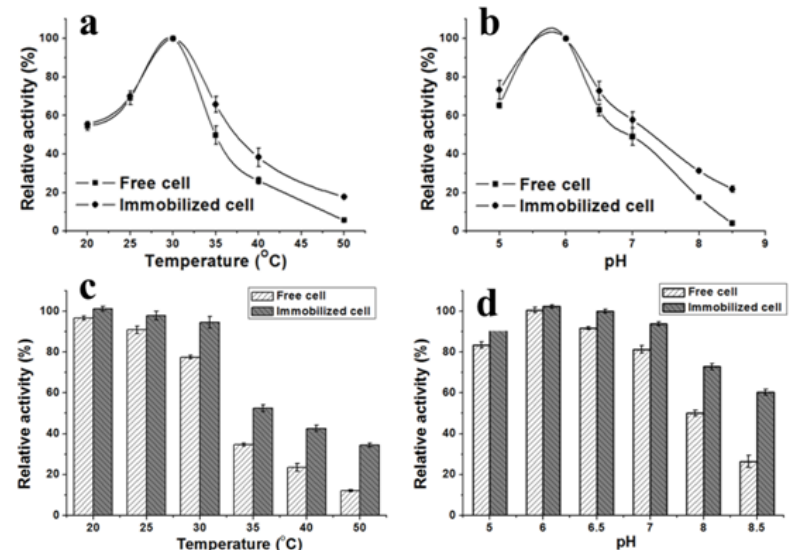

Figure 3: Effects of temperature (a) and $\mathrm{pH}(\mathrm{b})$ on the activity of the free and immobilized cells, Thermal (c) and $\mathrm{pH}(\mathrm{d})$ stability of the free and immobilized cells.

a: $5 \mathrm{mg}$ cells, $10 \mathrm{~g}$ glycerol/l, sodium phosphate buffer $(\mathrm{pH} 6)$, temperature ranging from $20-50^{\circ} \mathrm{C}$; b: $5 \mathrm{mg}$ cells, $10 \mathrm{~g}$ glycerol $/ \mathrm{l}, 100 \mathrm{mM}$ sodium phosphate buffer $(\mathrm{pH}$ from 5 to 8.5$)$, at $30^{\circ} \mathrm{C}$; $\mathrm{c}$ : The samples were pre-incubated at temperature ranging from 25 to $50^{\circ} \mathrm{C}$ for 12 hours and the residual activity was measured at $\mathrm{pH} 6.0$ at $30^{\circ} \mathrm{C}$; d: The samples were pre-incubated at $\mathrm{pH}$ ranging from 5 to 8.5 for 12 hours and the residual activity was measured at $\mathrm{pH} 6.0$ at $30^{\circ} \mathrm{C}$.

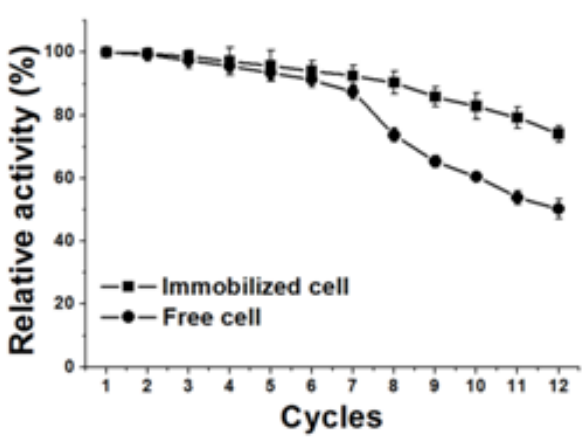

Figure 4: Reusability of the immobilized cells. Reaction conditions: $5 \mathrm{mg}$ cells, $100 \mathrm{mM}$ sodium phosphate buffer $(\mathrm{pH} 6)$, at $30^{\circ} \mathrm{C}$. After each run, the immobilized cells were separated by filtration and the free cells were separated by centrifugation $(10,000 \mathrm{rpm})$, washed with phosphate buffer $(\mathrm{pH} 6.0)$ for 2 times. The initial activities of the free and immobilized cells were defined as $100 \%$.

\section{Acknowledgements}

This work was funded by The National Natural Foundation of China (NO.21076079), Open Funding Project of the State Key Laboratory of Bioreacto Engineering and the Fundamental Research Funds for the Central Universities.

\section{References}

1. Mogi T, Matsushita K, Murase $\mathrm{Y}$, Kawahara $\mathrm{K}$, Miyoshi $\mathrm{H}$, et al. (2009) Identification of new inhibitors for alternative NADH dehydrogenase (NDH-II) FEMS Microbiol Lett 291: 157-161.

2. Behera S, Kar S, Mohanty RC, Ray RC (2010) Comparative study of bio-ethanol production from mahula (Madhuca latifolia L.) flowers by Saccharomyces cerevisiae cells immobilized in agar agar and Ca-alginate matrices. Appl Energ 87: $96-100$.

3. Wang JY, Chao YP (2006) Immobilization of Cells with Surface-Displayed Chitin-Binding Domain. Appl Environ Microb 72: 927-931.

4. Orrego CE, Salgado N, Valencia JS, Giraldo GI, Giraldo OH, et al. (2010) Novel chitosan membranes as support for lipases immobilization: characterization aspects. Carbohyd Polym 79: 9-16.

5. Jayakumar R, Prabaharan M, Reis RL, Mano JF (2005) Graft copolymerized chitosan-present status and applications. Carbohyd Polym 62: 142-158.

6. Kumar V, Jahan F, Raghuwanshi S, Mahajan RV, Saxena RK (2013) Immobilization of Rhizopus oryzae lipase on magnetic $\mathrm{Fe}_{3} \mathrm{O}_{4}$-chitosan beads and its potential in phenolic acids ester synthesis. Biotechnol Bioproc Eng 18: 787-795.

7. Seol YJ, Lee JY, Park YJ, Lee YM, Young-Ku, et al. (2004) Chitosan sponges as tissue engineering scaffolds for bone formation. Biotechnol Lett 26: 10371041.

8. Ramos R, Carvalho V, Gama M (2006) Novel hydrogel obtained by chitosan and dextrin-VA copolymerization. Biotechnol Lett 28:1279-1284.

9. Chu XH, Shi XL, Feng ZQ, Gu ZZ, Ding YT (2009) Chitosan nanofiber scaffold enhances hepatocyte adhesion and function. Biotechnol Lett 31: 347-352.

10. Anitha A, Divya Rani VV, Krishna R, Sreeja V, Selvamurugan N, et al. (2009) Synthesis, characterization, cytotoxicity and antibacterial studies of chitosan, O-carboxymethyl, N, O-carboxymethyl chitosan nanoparticles. Carbohydr Polymers 78: 672-677.

11. Tang CY, Zhang Q, Wang K., Fu Q, Zhang CL (2009) Water transport behavior of chitosan porous membranes containing multi-walled carbon nanotubes (MWNTs). J Membrane Sci 337: 240-247.

12. Santos DES, Neto CGT, Fonseca JLC, Pereira MR (2008) Chitosan macroporous asymmetric membranes: preparation, characterization and transport of drugs. J Membrane Sci 325: 362-370.

13. Zeng XF, Ruckenstein E (1996) Control of Pore Sizes in Macroporous Chitosan and Chitin Membranes. Ind Eng Chem Res 35: 4169-4175. 